ISSN 1810-3030 (Print) 2408-8684 (Online)

Journal of Bangladesh Agricultural University

Journal home page: http://baures.bau.edu.bd/jbau, www.banglajol.info/index.php/JBAU

\title{
Performance evaluation of a manual and a motor-operated maize seeder
}

\author{
Md. Samiul Basir ${ }^{1}$, Muhammad Mustagis Billah ${ }^{2}$ and ${ }^{凶}$ Muhammad Ashik-E-Rabbani $^{1}$
}

${ }^{1}$ Department of Farm Power and Machinery, Bangladesh Agricultural University, Mymensingh-2202, Bangladesh

${ }^{2}$ Department of Computer Science and Mathematics, Bangladesh Agricultural University, Mymensingh-2202, Bangladesh

\begin{tabular}{l} 
ARTICLE INFO OPENOACces \\
Article history: \\
Received : 04 December 2018 \\
Accepted : 26 February 2019 \\
Published: 30 June 2019 \\
\hline
\end{tabular}

Keywords:

Maize seeder, motor operated, seed spacing, field efficiency, missing rate

\section{Correspondence:}

Md. Ashik-E-Rabbani

凶: ashiks424@yahoo.com

\begin{abstract}
A motor-operated maize seeder was designed and fabricated. The performance of the seeder was tested in laboratory and compared with a manual-operated seeder. Hybrid maize seed variety, Sunshine NK40 by Syngenta, was used for the performance test of the seeder during January to April/2017. The two seeders, manual-operated and motor-operated, provided an average seed spacing of $22.48 \mathrm{~cm}$ and $20.94 \mathrm{~cm}$, respectively, while the standard seed spacing for maize is $20 \mathrm{~cm}$. The seed spacing of the motor-operated seeder varied from the standard value because of the trapping of seed between the seed hopper and metering device. The missing rate of the manual seeder was $13.2 \%$ while the motor-operated seeder provided a missing rate of $5.9 \%$. Due to constant forward speed, the motor-operated seeder resulted in 2.3 times lesser missing rate than the manual seeder. The seed rate of the manual- and motor-operated seeder was found to be $30 \mathrm{~kg} / \mathrm{ha}$ and $25.7 \mathrm{~kg} / \mathrm{ha}$, respectively, although both the seeders were calibrated to maintain a constant seed rate of $25 \mathrm{~kg} / \mathrm{ha}$. The field capacity and field efficiency of the existing manual seeder was found $0.128 \mathrm{ha} / \mathrm{h}$ and $76.65 \%$, respectively, whereas the field capacity and field efficiency of the motor-operated seeder was found $0.135 \mathrm{ha} / \mathrm{h}$ and $74.76 \%$, respectively. The motor-operated seeder has a limitation of time loss during turning and the required time loss resulted in low field capacity and field efficiency. Break-even analysis shows that at the yearly use of 0.23 hectares, the operation cost of manual seeder and hand application method were the same. Therefore, manual seeder will be beneficial to the farmers when the annual use exceeds 0.23 hectares of land. Compared to manually-operated seeder, the motor-operated seeder can reduce seed requirement by reducing missing rate and save labor and time of operation if the time loss during turning can be minimized.
\end{abstract}

\section{Introduction}

Maize is one of the most cultivated crops in Bangladesh, and most cultivation operations are done manually. Manual planting of maize seed is the traditional system of sowing where seeds sown per hill are more than the prescribed amount. This often causes over-population of seeds and, consequently, reduces yield. This method also requires a lot of labor and time. In case of maize cultivation, farmers use labor-intensive line sowing, which indicates scope of introduction of planters (Ahmad et al., 2014). Now-a-days, seeders are being introduced among farmers. The manually-operated seeder is preferable to them because of their affordable cost. Seeder ensures sowing seeds at suitable spacing and seed rate.

The manual seeder, operated by human force also is a time-consuming machine requiring extra labor and, thus, increases cost. In manual seeders, proper spacing cannot be maintained due to improper rotation of the metering device. A motor-operated light-weight seeder can reduce drudgery and also ensure proper spacing.
Mondal et al. (2004) developed a power-tiller-operated plate-planter for planting maize and wheat at BARI and observed a planting capacity of 0.2 to $0.25 \mathrm{ha} / \mathrm{h}$ with a row and plant spacing of $75 \mathrm{~cm}$ and $25 \mathrm{~cm}$, respectively. Matin et al. (2008) tested a multi-crop power-tilleroperated inclined-plate planter for maize establishment in winter and summer seasons of 2005 in three districts of Bangladesh. The performance of the planter and profitability of using the planter was evaluated and compared with traditional practice. The average field capacity was $0.19 \mathrm{ha} / \mathrm{h}$, saving total cost of production to $32.8 \%$ and labor costs of $79.2 \%$ over traditional practice. It was also observed that $18 \%$ yield increases in mechanical method using power tiller operated plateplanter compared to the traditional practice of maize planting. Hoque and Gathala (2018) improved the power-tiller-operated planter by modifying its tines for bed and strip planting with a simple maize conversion kit and attached it to the seeder for planting maize. After evaluation, it was observed that the desired seed spacing $(20 \mathrm{~cm})$ and uniformity $(98 \%)$ could be achieved. This 
seeder was also tested for full tillage and strip tillage and compared with conventional planting method where modified PTOS machine-planted maize showed higher yield compared to the conventional practice (Hoque and Gathala, 2018). All the seeders discussed above were designed and developed for large farmer and need large investment. Thus, a small seeder is needed for the marginal farmers requiring less technical knowledge.

Metering mechanism is the heart of sowing machine, which has the function to distribute the seeds at a desired rate. In addition, calibration of a seeder is critical in getting the correct number of seeds per revolution of the runner wheel. The selection of seeder machine with a metering device is essential to suit for the crop and soil conditions. Bold seeds like ground nut or maize require seeders with an inclined cell plate or cup-feed type metering system (Rabbani et al., 2016a). The main purpose of sowing operation is to put the seeds in rows at desired depth, maintain seed to seed spacing, cover seeds with soil and provide proper compaction over the seed. The timeliness, labor cost and sowing efficiency of the machine, and uniformity of sowing is also responsible for optimum yield (Rabbani et al., 2016b).

There were some problems of a manually-operated seeder due to uneven rotation of the seeder drive wheel and fluctuation in forward speed of the machine. These cause uneven rotation of metering device and, consequently, the seed spacing remains non-uniform. When it is self-propelled, the seed metering device can rotate uniformly and the seed drops at distance apart. The fluctuation of forward speed can also be minimized as the machine is operated at a fixed forward speed by the power unit. Thus, concentrating on the aforementioned issues, this study was carried out to evaluate performance of a newly fabricated motoroperated seeder for maize seed and to compare the performance of the existing manual- and motor-operated seeders for maize.

\section{Materials and Methods}

This study was conducted at the workshop of Farm Power and Machinery Department of Bangladesh Agricultural University, Mymensingh during January to April/2017. The experimental site was a flat land containing sandy loam soil.

\section{Manual and motor-operated seeders}

Themanually-operated seeder was fabricated and tested in FPMD workshop (Fig. 1). The machine was pushtype with two metering devices for two seed hoppers. The power transmission system is a chain and sprocket system with the gear-pinion arrangement.

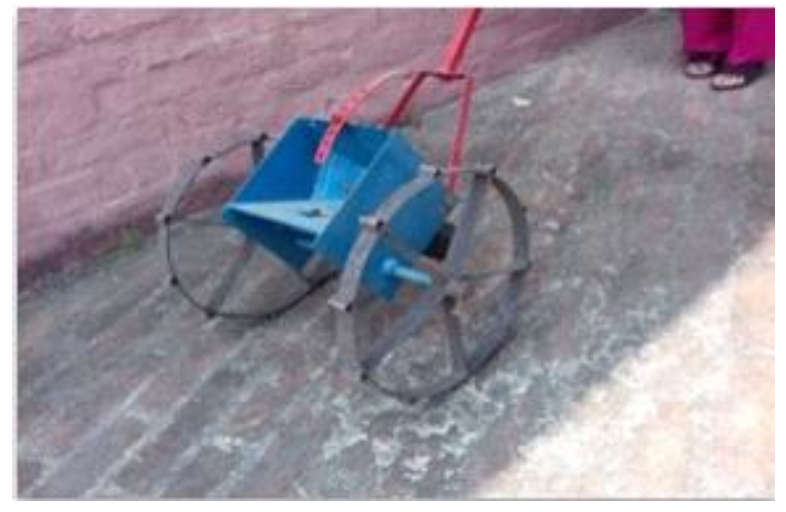

Fig. 1. Manual seeder

The two-row motor-operated seeder (Fig. 2) contains a single-phase DC motor of $0.75 \mathrm{hp}$, an aluminum motor controller, a switch, an accelerator (Fig. 3), two batteries with battery cages, two seed hoppers, two metering devices, two runner wheels, sweep-type bed former, a supporting wheel and two seed tubes. The specifications of a manual seeder and the motor-operated seeder are described in Table 1.

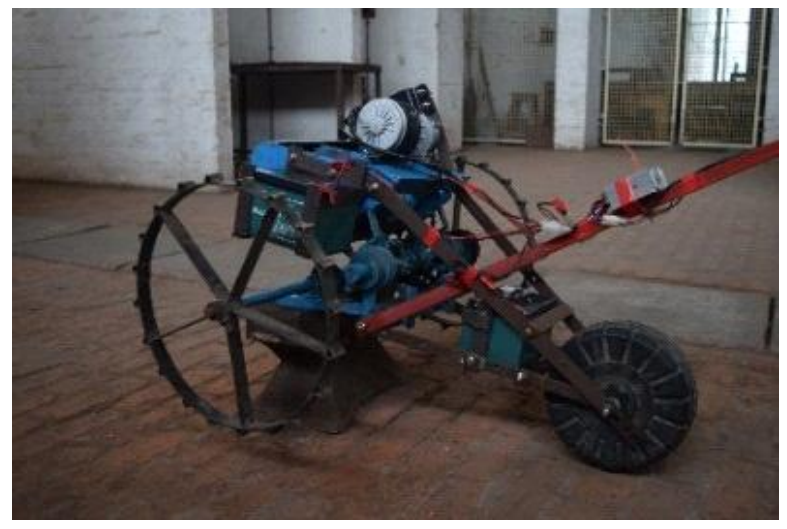

Fig. 2. Motor operated seeder

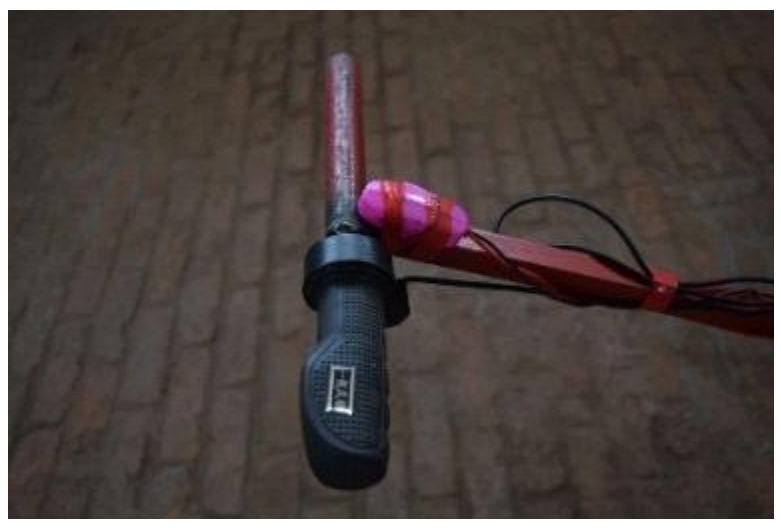

Fig. 3. Handle and switch of motor-operated seeder 
Table 1. Specifications of a manual seeder and the motor-operated seeder

\begin{tabular}{|c|c|c|c|}
\hline Name of the component & No. of items & Dimension (cm) & Material \\
\hline \multicolumn{4}{|l|}{ Manual seeder } \\
\hline Seed hopper & 1 & height 20.3 , diameters 21.6 and 17 & Plastic sheet \\
\hline Plate type seed metering device & 1 & diameter $16.8,8$ cells & Plastic \\
\hline Seed tube & 1 & height 30.48 and diameter 2.54 & Plastic \\
\hline Sweep type bed former & 2 & diameter 25.4 & MS bar \\
\hline Runner wheel & 2 & diameter 40.64 & Rubber \\
\hline Handle & 1 & length 60.9 and diameter 2.54 & MS bar \\
\hline Nut \& bolts & 24 & & MS bar \\
\hline Depth Control devices & 2 & length 33 & MS bar \\
\hline \multicolumn{4}{|l|}{ Motor-operated seeder } \\
\hline Motor(single phase, dc, 24 volt) & 1 & 9.5 Diameter & \\
\hline Motor controller & 1 & length 7.5 , width 5 , height 3.6 & Aluminum \\
\hline Switch & 1 & & Plastic \\
\hline Accelerator & 1 & & Rubber \\
\hline Battery(12 volt) & 2 & length 14.9 , width9.8, height 10 & \\
\hline Seed hopper & 2 & height 12.7 , length 9.2 and width 25.5 & Iron sheet \\
\hline Plate type seed metering device & 2 & 16.8 diameter, 8 cells & Plastic \\
\hline Seed tube & 2 & 30.48 height and diameter 254 & Plastic \\
\hline Sweep type bed former & 2 & diameter 25.4 & MS bar \\
\hline Runner wheel & 2 & diameter 40.64 & Rubber \\
\hline Supporting wheel & 1 & diameter 23, thickness 9 & Plastic \\
\hline Battery cage & 2 & length 6 , width 4.5 , height 10 & MS Flat bar \\
\hline Chain \& sprockets & 2 sets & & Cast Iron \\
\hline
\end{tabular}

Test of seeders:

The performance of a manual and a motor-operated seeder was conducted based on seed spacing, missing rate, field capacity and efficiency of the machines for maize seeds. In the experiment, cell-type metering devices were used, and seed sowing was done in furrow. The manually-operated seeder was tested at the testing bed of the Farm Power and Machinery departmental (FPMD) workshop. The motor-operated seeder was fabricated at FPMD workshop and tested both in the laboratory and testing bed. A photograph of the seeded during calibration is shown in Fig. 4. The metering device used for maize seed sowing is shown in Fig. 5.

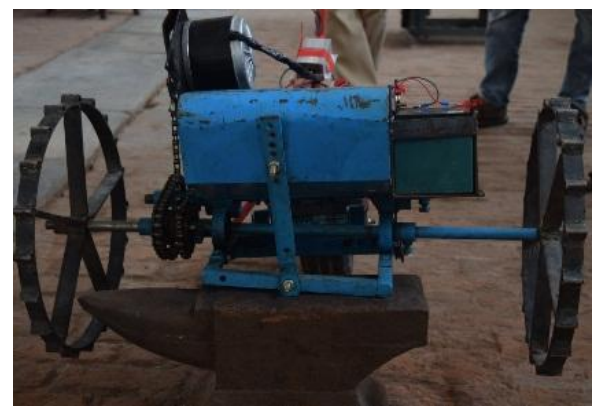

Fig. 4. Motor-operated seeder during calibration

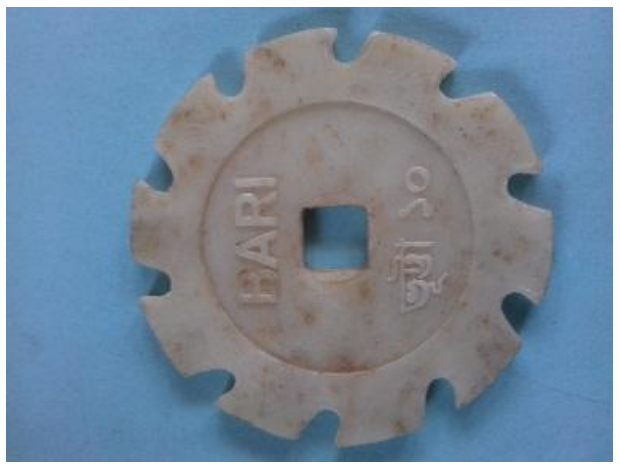

Fig. 5. Seed metering device

\section{Laboratory tests:}

Parameters of laboratory tests like self-weight, seed rate, etc. were measured in the laboratory.

Self-weight of the seeder: The self-weight of a machine is related to the operational ease of the machine. The self-weight of the applicator was measured by a digital strain gauge scale balance.

Seed rate: By calibrating the seeder in laboratory, seed rate was determined. Uniformity of seed rate on the plate-type seed metering device was maintained by adjusting the gap of seed meter. The seed rate of different types of seed for seeder machine was calculated by (Asha, 2015).

Seed rate $(\mathrm{kg} / \mathrm{ha})=$

$$
\text { Seed obtained by } 10 \text { revolutionof drive wheel(gm) }
$$$$
\text { Width of seeder }(\mathrm{m}) \times \text { circum ference of drive wheel }(\mathrm{m})
$$

Field test: Field test was done in the testing bed containing sandy loam soil. The length and width of the testing bed was $13.41 \mathrm{~m}$ and $2.13 \mathrm{~m}$, respectively.

Seed spacing: Distance of dropped seeds, maintained by the seeder, was measured carefully. After each pass of the seeding operation, one observer measured the spacing of dropped seeds in the field (Fig. 6). After observation, the average distance of dropped seeds was calculated.

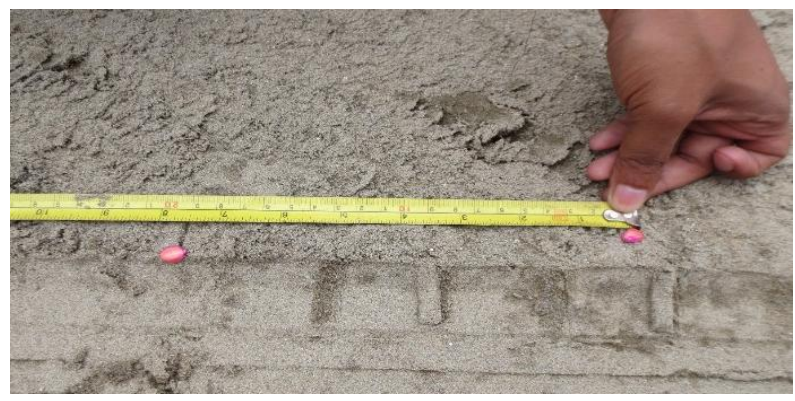

Fig. 6. Distance between two dropped seeds 
Missing rate: Missing rate of maize seed was determined by the following expression:

Missing rate $(\%)=\frac{\mathrm{N}_{1}}{\mathrm{~N}_{2}} \times 100$

Where $\mathrm{N}_{1}$ is number of maize seed missing during pickup by metering device into seed tube and $\mathrm{N}_{2}$ is number of maize seed dropped by the metering device if no missing occurred and there is no more than one seed per cell.

Field capacity: Theoretical and effective field capacity of the seeder was determined by equation (3) and (4), respectively (Kepner et al., 1978). Theoretical field capacity is given by

$$
\mathrm{C}_{\text {th }}=\frac{\mathrm{Sw}}{10}
$$

Where, $\mathrm{C}_{\mathrm{th}}$ is theoretical field capacity $(\mathrm{ha} / \mathrm{h}), \mathrm{S}$ is forward speed $(\mathrm{km} / \mathrm{h})$ and $\mathrm{w}$ is width of coverage $(\mathrm{m})$. The effective field capacity is expressed by

$$
\mathrm{C}_{\text {eff }}=\frac{\mathrm{A}}{\mathrm{T}}
$$

Where $\mathrm{C}_{\text {eff }}$ is effective field capacity (ha/h), A is field coverage (ha/h) and $\mathrm{T}$ is actual time of operation.

Field efficiency: Field efficiency of the machine was calculated by (Kepner et al., 1978):

$$
\text { Field efficiency,e }(\%)=\frac{\text { Effective field capacity }\left(\frac{\mathrm{ha}}{\mathrm{h}}\right)}{\text { Theoretical field capacity }\left(\frac{\mathrm{ha}}{\mathrm{h}}\right)} \times 100 \%
$$

Seeder operational cost: Operation cost consists of (a) fixed cost like depreciation, interest, taxes and insurance, shelter etc. and (b) variable cost like labor, fuel, oil, repair and maintenance etc.

Fixed cost: Fixed cost is defined as one, which remains unchanged when level of output alters (i.e. it applies to a resource that is fixed in quantity). Fixed cost comprises those costs, which have to bear regardless of the machine is used, namely, depreciation, housing, interest on investment and tax (if any). Fixed costs are fixed in total, but decline per ha, as the annual use of the machine is increased (Barnard and Nix, 1979).

The straight-line method is the simplest for the calculation of depreciation and normally used in budgeting, since the concern is usually only with the average annual cost of machine (Barnard and Nix, 1979). Therefore, in calculation of fixed cost, a straightline depreciation is assumed and the following equation (6) was used.

$$
\text { Annual depreciation, } \mathrm{D}(\mathrm{tk})=\frac{\mathrm{P}-\mathrm{S}}{\mathrm{L}} \text {. }
$$

Where $\mathrm{D}=$ Depreciation $(\mathrm{Tk} / \mathrm{yr}), \mathrm{P}=$ Purchase price of machine or implement $(\mathrm{Tk}), \mathrm{S}=$ Salvage value $(\mathrm{Tk})$ and $\mathrm{L}=$ Life of machine (yr) (assumed 5 years for seeders).
The interest on investment in a seeder is included in fixed cost estimation. This charge is made since the invested money cannot be used for some other interest paying enterprises even if the investment money is not actually borrowed. The following equation was used for the calculation of interest on invest.

Interest on investment, $\mathrm{I}\left(\frac{\mathrm{tk}}{\mathrm{yr}}\right)=\frac{\mathrm{P}+\mathrm{S}}{2} \times \mathrm{i}$

Where, $\mathrm{I}=$ Interest on investment $(\mathrm{Tk} / \mathrm{yr})$ and $\mathrm{i}=$ Interest rate (assume 12\%).

Insurance should be carried on farm machinery to allow for replacement in case of a disaster or accident. If insurance is not carried, the risk is assumed by the rest of the farm business. There is a tremendous variation in housing. Providing shelter, tools, and maintenance equipment for machinery will result in fewer repairs in the field and less deterioration of mechanical parts and appearance from weathering. To simplify calculating TIH (Tax, Insurance and Housing) costs, they can be lumped together as 2.5 percent of the purchase price.

Variable costs: The variable cost changes when the level of output alters. Variable costs depend on hourly labor cost, fuel, oil, repair and maintenance cost and the required working hours for each field operations. Repair and maintenance cost of seeder involved the price of replaceable parts after a regular interval and some incidental cost during operation. These were mainly bearings, power transmission chain, nuts and bolts of furrow opener and furrow closer. This cost was considered $0.08 \%$ of purchase price for 100 hours of the seeder annual use (Hunt, 1995). The cost of operator/labor was calculated as the labor rate in $\mathrm{Tk} / \mathrm{h}$.

Operating cost: Operating costs are recurring costs that are necessary to operate and maintain a machine during its useful life (White et al., 1989). Annual operating costs were divided into fixed costs and variable costs. All calculated fixed costs and variable costs were converted into $\mathrm{Tk} / \mathrm{ha}$ and then summation of fixed and variable costs had given operating costs in Tk/ha.

Break-even use: It is the common phenomena of costing any agricultural machinery where the total cost per hectare decreases as annual use increases. This concept was used to determine the break-even use. Operation of seeder on the break-even usage, that is, the amount of land use for which the costs for seeding operation with seeder is the same as the costs of hand application. The break-even use (BEU) can be determined by the following equation.

Break-even use, BEU (ha/yr) = Fixed cost (Tk/yr)

Manual sowing cost(Tk/ha) - Variable cost of seeder(Tk/ha) 


\section{Results and Discussion}

Self-weight: The manual seeder had a self-weight of 17 $\mathrm{kg}$. The self-weight of the motor-operated seeder was $31.7 \mathrm{~kg}$. This additional weight for the motor-operated seeder was due to batteries, DC motor and modification of chassis to hold them.
Missing rate of the two seeders: The results of missing rate for maize sowing observed from the laboratory test of the motor-operated and manual-operated seeders are presented in Table 2 and Table 3, respectively.

Table 2. Missing rate of motor-operated seeder

\begin{tabular}{ccccccc}
\hline Obs. no. & $\begin{array}{c}\text { Length of } \\
\text { field }(\mathrm{cm})\end{array}$ & $\begin{array}{c}\text { Standard distance to } \\
\text { drop seed }(\mathrm{cm})\end{array}$ & $\begin{array}{c}\text { Number of seeds } \\
\text { dropped theoretically }\end{array}$ & $\begin{array}{c}\text { Actual number of } \\
\text { seeds dropped }\end{array}$ & $\begin{array}{c}\text { Missing } \\
\text { rate }(\%)\end{array}$ & $\begin{array}{c}\text { Average missing } \\
\text { rate }(\%)\end{array}$ \\
\hline 1 & 558 & 20 & 28 & 26 & 7.1 & \\
2 & 558 & 20 & 28 & 26 & 7.1 & 5.9 \\
3 & 558 & 20 & 28 & 27 & 3.5 & \\
\hline
\end{tabular}

Table 3. Missing rate of manual seeder

\begin{tabular}{ccccccc}
\hline Obs. no. & $\begin{array}{c}\text { Length of } \\
\text { field }(\mathrm{cm})\end{array}$ & $\begin{array}{c}\text { Standard distance } \\
\text { to drop seed }(\mathrm{cm})\end{array}$ & $\begin{array}{c}\text { Number of seeds } \\
\text { dropped theoretically }\end{array}$ & $\begin{array}{c}\text { Actual number of } \\
\text { seeds dropped }\end{array}$ & $\begin{array}{c}\text { Missing rate } \\
(\%)\end{array}$ & $\begin{array}{c}\text { Average missing } \\
\text { rate }(\%)\end{array}$ \\
\hline 1 & 558 & 20 & 28 & 24 & 14.3 & \\
2 & 558 & 20 & 28 & 25 & 10.7 & 13.1 \\
3 & 558 & 20 & 28 & 24 & 14.3 & \\
\hline
\end{tabular}

Comparative missing rate: The average missing rate was $13.1 \%$ for the manual seeder and $5.9 \%$ for motoroperated seeder.

Seed spacing of maize for the motor-operated seeder: The seed spacing for the three trials were found as 21.12 $\mathrm{cm}, 22.12 \mathrm{~cm}$ and $19.57 \mathrm{~cm}$. Average seed spacing was $20.94 \mathrm{~cm}$, which is very close to the standard value of 20 cm. Fig. 7 shows distance of dropped seeds (total 77) in 3 trials. The maximum seed dropped at a distance between $18 \mathrm{~cm}$ and $23 \mathrm{~cm}$. About $9.21 \%$ seeds were dropped at less than $13 \mathrm{~cm}$ apart. This happened when the seed size was too small, and the metering device holds more than one seed. About $7.89 \%$ seeds were dropped at a distance greater than $33 \mathrm{~cm}$ and $13.15 \%$ at a distance of $29-33 \mathrm{~cm}$, which increased the missing rate.

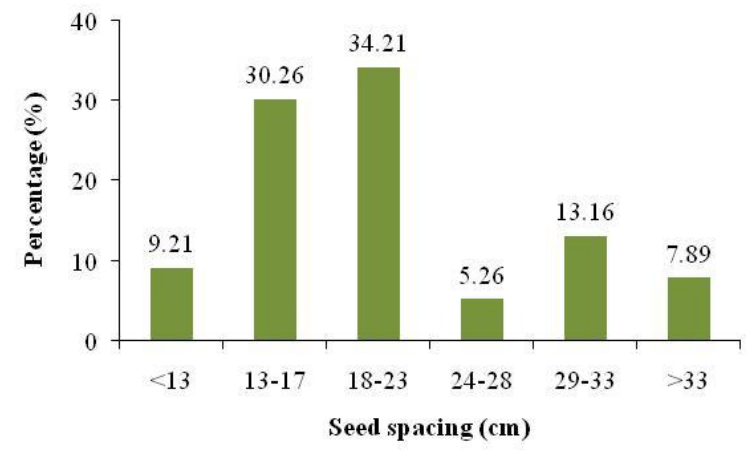

Fig. 7. Spacing of maize seed for the motor-operated seeder

Comparative seed spacing: Fig. 8 shows a comparison of the average seed spacing of maize sown by the manual seeder and motor-operated seeder. The average seed spacing for the manual seeder was $22.48 \mathrm{~cm}$. The motor-operated seeder provided an average seed spacing of $20.94 \mathrm{~cm}$.

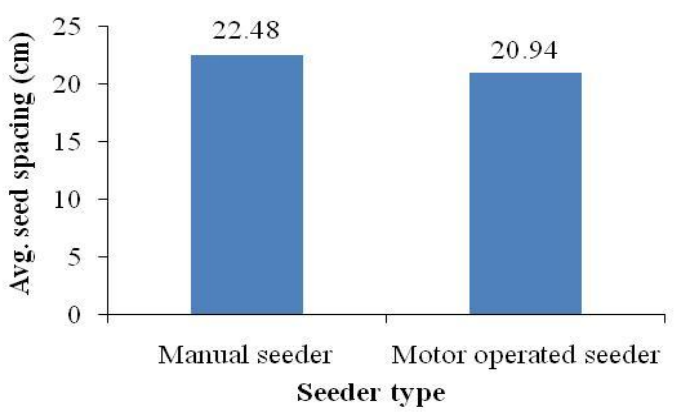

Fig. 8. Seed spacing of two seeders

Field capacity of the seeders: The field capacity of the manually-operated seeder was found $0.128 \mathrm{ha} / \mathrm{h}$ and that of motor-operated seeder was $0.135 \mathrm{ha} / \mathrm{h}$. Fig. 9 demonstrates comparative field capacity of the two seeders. The average forward speed for the manual seeder was $2.3 \mathrm{~km} / \mathrm{h}$ and that of the motor-operated seeder was $2.5 \mathrm{~km} / \mathrm{h}$.

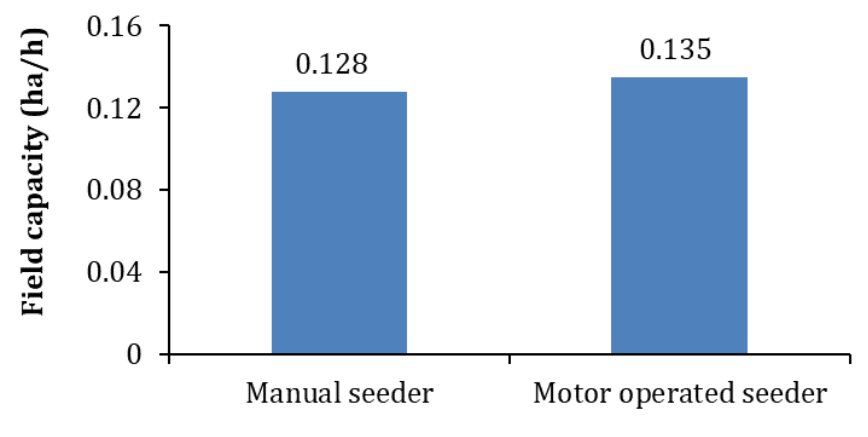

\section{Seeder type}

Fig. 9. Field capacity of two seeders

Field efficiency of the seeders: The manually-operated seeder performs at an efficiency of $76.65 \%$ but the motor-operated seeder performed at $74.76 \%$ efficiency (Fig. 10). The turning time of motor-operated seeder was relatively higher that caused reduction in its efficiency. 


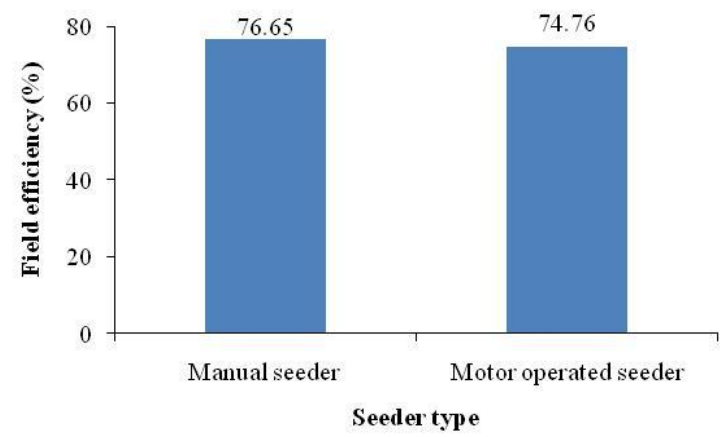

Fig. 10. Field efficiency of two seeders

Seed rate: The average seed rate of the manual seeder was $32 \mathrm{~kg} / \mathrm{ha}$ while the motor-operated seeder has a seed rate of $25.78 \mathrm{~kg} / \mathrm{ha}$. Fig. 11 illustrates seed rates of the two seeders and their comparison with the standard rate for maize. The standard seed rate for maize was obtained from BARI Handbook (2014). It is observed that the seed rate varies with the time required for revolutions and seed metering devices. Skidding was also a reason for variation in optimum seed rates. Besides, some of the seeds were trapped between the seed hopper and the metering device due to the uneven size of the seeds.

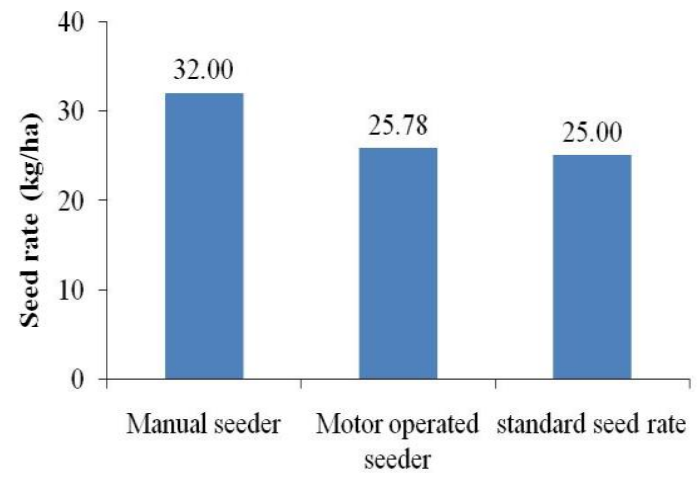

Fig. 11. Seed rate of two seeders with standard value

Operational cost of seeders: Cost of operation of two seeders was calculated based on their field capacity and fabrication price. Table 4 presents the cost parameters of two seeders along with manual sowing.

Table 4. Operational costs of motor-operated seeder, manual seeder and manual sowing

\begin{tabular}{|c|c|c|c|c|}
\hline & Cost items & Motor-operated seeder & Manual seeder & Manual Sowing \\
\hline \multirow{6}{*}{$\begin{array}{l}\text { Fixed cost } \\
\text { items }\end{array}$} & Purchase price of Seeder $(\mathrm{P})(\mathrm{Tk})$ & 10,000 & 4,900 & - \\
\hline & Salvage value $(\mathrm{S})(10 \%$ of $\mathrm{P})(\mathrm{Tk})$ & 1,000 & 490 & - \\
\hline & Working life (L) (yr) & 5 & 5 & - \\
\hline & Interest on investment $(\mathrm{Tk} / \mathrm{yr})$ & 550 & 270 & - \\
\hline & Sheltering $(2.5 \%$ of $\mathrm{P})(\mathrm{Tk} / \mathrm{yr})$ & 250 & 123 & - \\
\hline & Interest rate $(\%)$ & $12 \%$ & $12 \%$ & - \\
\hline \multirow{10}{*}{$\begin{array}{l}\text { Variable cost } \\
\text { items }\end{array}$} & power consumption cost $(\mathrm{Tk} / \mathrm{h})$ & 3.00 & 0.00 & - \\
\hline & Repair and Maintenance $(0.035 \%$ of $\mathrm{P})(\mathrm{Tk} / \mathrm{h})$ & 3.50 & 1.72 & - \\
\hline & Repair and Maintenance cost (Tk/yr) & 1,050 & 823 & - \\
\hline & Cost of labor $(\mathrm{Tk} / \mathrm{h})$ & 0 & 0 & 50 \\
\hline & Cost of operator $(\mathrm{Tk} / \mathrm{h})$ & 50 & 50 & - \\
\hline & Average working hours per day & 5 & 8 & - \\
\hline & Average working day per year & 60 & 60 & - \\
\hline & Average working hours per year (h/yr) & 300 & 480 & - \\
\hline & Field capacity (ha/h) & 0.135 & 0.128 & 0.0084 \\
\hline & Average field coverage per year (ha/yr) & 40.5 & 61.44 & - \\
\hline \multirow{3}{*}{ Fixed cost } & Depreciation $(\mathrm{Tk} / \mathrm{yr})$ & $1,800.00$ & 882.00 & - \\
\hline & Interest on investment $(\mathrm{Tk} / \mathrm{yr})$ & 550 & 270 & - \\
\hline & Sheltering (Tk/yr) & 250 & 123 & - \\
\hline Total fixed co & st (Tk/yr) & $2,600.00$ & $1,274.00$ & - \\
\hline \multirow{5}{*}{ Variable cost } & Fuel (Tk/h) & 3 & 0 & - \\
\hline & Lubricant (Tk/h) & 0.45 & 0 & - \\
\hline & Repair and Maintenance cost $(\mathrm{Tk} / \mathrm{h})$ & 3.5 & 1.715 & - \\
\hline & Cost of operator $(\mathrm{Tk} / \mathrm{h})$ & 50 & 50 & - \\
\hline & Cost of labor $(\mathrm{Tk} / \mathrm{h})$ & 0 & 0 & 50 \\
\hline \multicolumn{2}{|c|}{ Total variable cost $(\mathrm{Tk} / \mathrm{h})$} & 56.95 & 51.72 & - \\
\hline \multicolumn{2}{|c|}{ Total variable cost $(\mathrm{Tk} / \mathrm{ha})$} & 421.85 & 404.02 & - \\
\hline \multicolumn{2}{|c|}{ Operating cost (Tk/ha) } & 486.05 & 424.76 & 5952.38 \\
\hline
\end{tabular}

The total costs of operation by power-operated seeder and manual seeder were 486.05 and $424.76 \mathrm{Tk} / \mathrm{ha}$, respectively, whereas cost for hand operation was $5952.38 \mathrm{Tk} / \mathrm{ha}$. The results indicate that $91.83 \%$ and $92.86 \%$ costs were saved by power-operated seeder and manual seeder, respectively over hand sowing. On the other hand, about $14 \%$ operating cost was increased after adding the motor and other accessories to the manualoperated seeder. This is due to the high price of the motor, which acted as a prime mover for seeding operation in power-operated seeder.

Break-even analysis: The results of break-even analysis (comparison of hand sowing and both of the seeder 
machines) are presented in Figure 12. It shows that a farmer having only any one of the two seeder machines has to incur a cost of Tk 2600 and Tk 1274 by poweroperated seeder and manual seeder, respectively. However, with the increase in annual use of land the cost of hand sowing increased quite steeply compared to both of the seeders. At the yearly use of 0.23 hectares, the operation costs of manual seeder and hand sowing were the same (Figure 12). Therefore, manual seeder will be beneficial to the farmers when the annual use exceeds 0.23 hectares of land. Similarly, power-operated seeder may be beneficial to the farmer when the annual use exceeds 0.47 hectares of land.

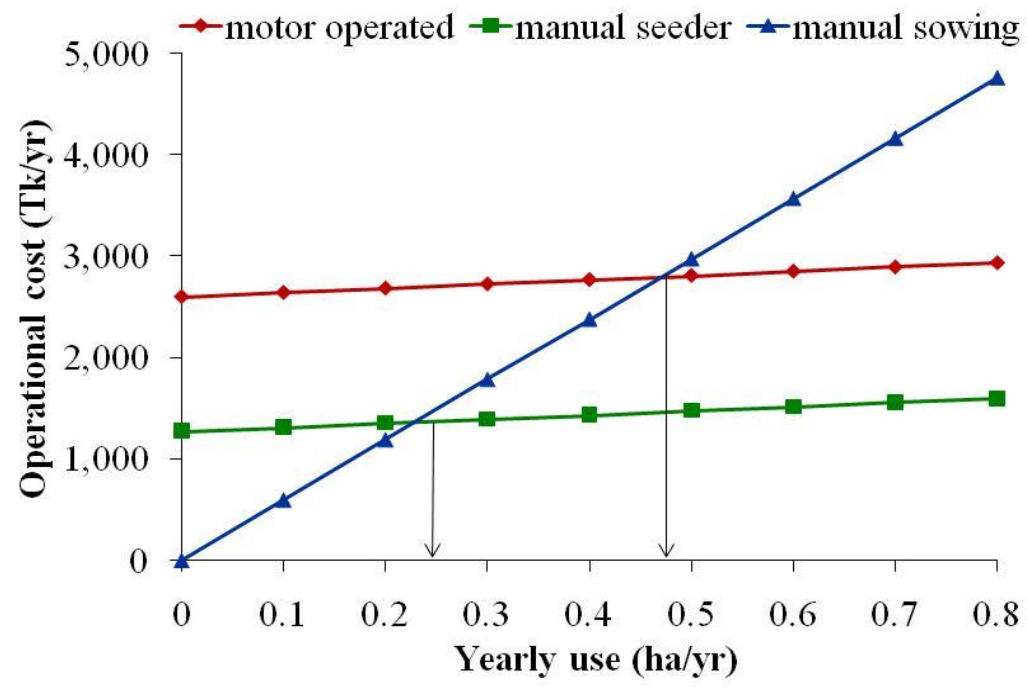

Fig. 12. Break-even use of seeders

\section{Conclusion}

The seed spacing of the motor-operated seeder varies from the standard value because of the trapping of seed between seed hopper and metering device. The missing rate of the motor-operated seeder was found 2.3 times lesser than that of manual seeder. The effective field capacity of the motor-operated seeder was satisfactory compared to the theoretical capacity of the machine. The dissimilarity in field capacity occurred for the manual seeder due to variation in walking speed were minimized in the motor-operated seeder as the motor RPM can be kept fixed in motor-operated seeder. The field capacity increased because of its uniformity and timeliness. The motor-operated seeder has a smaller field efficiency compared to the manual seeder since turning of the motor-operated seeder takes a considerably higher time than the manual seeder. So, the effective field capacity was much lower than that of the theoretical. The seed rate also varied for the manual seeder, but in case of the motor-operated seeder, it is closer to the standard value for maize sowing. The manually-operated seeder is time consuming and labor oriented. Sowing of maize by motor-operated seeder achieves the timeliness and uniformity of seeding and lessens labor requirement with more accuracy in sowing seeds. Therefore, it can be concluded that cultivation of maize by using motoroperated seeder is more effective than the manual seeder.

\section{References}

Ahmad, H.B., Amin, M.A., Hussain, I., Rafique, M.C., Naveed, M., Awais, M.A., Shafiq, M. and Aqeel, M. 2014. Effect of different sowing dates on yield contributing trials of mash bean (Vigna Mungo L.). International Journal of Agronomy and Agricultural Research, 5(6), 42-48.

Asha, J.F. 2015. Modification of the push type seeder for maize cultivation. MS thesis, Department of Farm Power and Machinery, Bangladesh Agricultural University.

Barnard, C.S. and Nix, J.S. 1979. Farm Planning and Control (2nd $\mathrm{ed}^{\mathrm{n}}$.) Cambridge University Press, Cambridge, LondonNew York-Melbourne.

Hoque, M.A. and Gathala, M.K. 2018. Improvement of power tiller operated seeder for maize planting. Fundamental and Applied Agriculture, 3(2), 474-479. https://doi.org/10.5455/faa.293468

Hunt, D. 1995. Farm Power and Machinery Management. Cost determination. 9th edition, Iowa State University Press, America.

Kepner, R.A., Bainer, R. and Barger, E.L. 1978. Principles of Farm Machinery. 3rd edition, pp. 209-234.

Matin, M.A., Roy, K.C. and Amin, M.N. 2008. Performance of BARI developed planter for establishment of maize. Agricultural Engineering International: The CIGR eJournal. Manuscript PM 07 023. Vol. X, pp. 1-7.

Mondal, M.R.I., Sultan, M.K., Nur, S., Sarker, M.J.U., Alam, M.S. and Rahman, M.H.H. 2014. Krishi Projukti Hatboi (Handbook on Agro-Technology). $6^{\text {th }}$ edition. BARI, Gazipur-1701, Bangladesh.

Rabbani, M.A., Chowdhury, S.T. and Sarker, T.R. 2016a. Performance evaluation of a single seeder machine for sowing different varieties of seed.Journal of Agricultural Machinery and Bioresource Engineering,7(1), 63-68.

Rabbani, M.A., Hossain, M.M., Asha, J.F. and Khan, N.A. 2016 b. Design and development of a low-cost planter for maize establishment. Journal of Science, Technology and Environment Informatics, 4(01), 270-279. https://doi.org/10.18801/jstei.040116.30

White, J.A., Agee, M.H. and Case, K.E. 1989. Principles of Engineering Economic Analysis (third edition.). John Wiley \& Sons. London New York Melbourne. 